\title{
THE MEANING OF ORNAMENTS IN THE HINDU AND BUDDHIST TEMPLES ON THE ISLAND OF JAVA (ANCIENT - MIDDLE - LATE CLASSICAL ERAS)
}

\author{
${ }^{1}$ Andre Halim. ${ }^{2}$ Dr. Rahadhian Prajudi Herwindo, ST., MT. \\ ${ }^{1}$ Student in the Bachelor's (S-1) Study Program in Architecture \\ at Parahyangan Catholic University \\ ${ }^{2}$ Senior lecturer in the Bachelor's (S-1) Study Program in Architecture \\ at Parahyangan Catholic University
}

\begin{abstract}
As one of the relics of the Classical Era, temples and shrines have been known as a means of worshipping the gods and goddesses or one's ancestors, especially in the religions of Hinduism and Buddhism. Observers often regard the ornaments of these temples as mere visual art objects, as eye candy that may beautify their outward appearance. However, when examined more closely, these ornaments carry a certain meaning in each of the temples. The aim of this research study is to explore the deeper significance of these ornaments and their location. This research can be classified as qualitative, using the descriptive-analytical method. Employing the Purposive Sampling method regarding ornamentation, eleven temples have been selected that meet the research requirements. Both Hinduism and Buddhism have been known to make a division into three worlds, namely the lower, middle and upper spheres. This division has also shaped the elements of temples into their respective head, body and legs/feet. Further categorization yields six motifs, all of which can be found in temples in various shapes, consisting of several types of ornament that embellish the three elements mentioned above. Each of the motifs carries a variety of meanings. In this research study, the relationship between the meanings and their exact location (placement) is analyzed, indicating that they are in keeping with the division into three worlds, but then again there are ones that do not follow that pattern, and still others that are not affected at all. Development of the physical shape of the ornaments has occurred in several ornaments, but the majority of the changes in their physical shape has left no impact on the meaning contained within these ornaments.
\end{abstract}

Keywords: temple, ornament, meaning, placement, physical shape

\section{MAKNA ORNAMEN PADA BANGUNAN CANDI HINDU DAN BUDDHA DI PULAU JAWA (ERA KLASIK TUA - KLASIK TENGAH - KLASIK MUDA)}

\author{
${ }^{1}$ Andre Halim. ${ }^{2}$ Dr. Rahadhian Prajudi Herwindo, ST., MT. \\ ${ }^{1}$ Mahasiswa S1 Program Studi Arsitektur Universitas Katolik Parahyangan. \\ 2 Dosen Pembimbing S1 Program Studi Arsitektur Universitas Katolik Parahyangan.
}

${ }^{1}$ Corresponding author: dre2012420042@gmail.com 


\begin{abstract}
Abstrak- Candi sebagai salah satu peninggalan arsitektur jaman Klasik, terutama dalam agama Hindu dan Buddha dikenal sebagai sarana pemujaan dewa atau nenek moyang. Seringkali orang memandang ornamen pada candi hanya sebagai objek seni visual, sebagai 'pemanis' yang mempercantik penampilan dari candi. Padahal jauh lebih dalam ornamen tersebut mengandung makna tertentu pada masing-masing bentuknya. Tujuan dari penelitian ini yaitu untuk mengetahui makna ornamen dan perletakannya pada candi. Penelitian yang dilakukan bersifat kualitatif, dengan menggunakan metode analisis deskriptif. Dengan menggunakan metode purposive sampling mengenai ornamen, dapat dipilih sebelas candi yang memenuhi syarat untuk digunakan sebagai objek penelitian. Dalam agama Hindu dan Buddha dikenal pembagian tiga dunia, yakni dunia bawah, dunia tengah, dan dunia atas. Pembagian tiga dunia ini terwujud pada elemen candi, yakni kepala, badan, dan kaki candi. Elemen ornamen dapat digolongkan menjadi enam motif, dimana semuanya ditemukan pada candi dengan berbagai jenis dan bentuk ornamen menghiasi ketiga elemen candi. Masing-masing motif memiliki makna yang beragam. Dalam penelitian ini kemudian dianalisis hubungan antara makna dengan penempatannya, bahwa terdapat makna yang sesuai mengikuti pembagian tiga dunia, ada makna yang tidak sesuai, ada pula yang tidak terpengaruh dengan penempatan tersebut. Perkembangan wujud fisik ornamen terjadi pada beberapa ornamen, namun mayoritas perubahan wujud fisik bentuknya tidak mempengaruhi makna dalam ornamen tersebut.
\end{abstract}

Kata-kata kunci: candi, ornamen, makna, perletakan, wujud fisik

\title{
1 PENDAHULUAN
}

Dalam sejarah perkembangan Nusantara, pada abad ke-5 hingga abad ke-14 kerajaan Hindu dan Budha banyak berkembang di wilayah Indonesia bagian barat, khususnya di pulau Jawa. Kerajaan tersebut mewariskan banyak peninggalan bersejarah, dari segi arsitektur salah satunya ialah candi. Fungsi candi sebagai tempat pemujaan dewa atau leluhur identik dengan elemenelemen ornamen yang menghiasi sebagian maupun seluruh bagian candi. Elemen ornamen yang merupakan fasad pada bangunan candi tidak hanya sebagai elemen penghias visual saja, tetapi mengandung arti tertentu sesuai prinsip Hindu-Buddha dan era didirikannya candi. Makna tersebut yang seringkali tidak diketahui banyak orang, dan fenomena ini menjadi menarik untuk diteliti lebih lanjut.

Dalam perwujudannya, perletakan ornamen tidak dapat diletakan sembarang. Terdapat alasan-alasan tertentu yang didasarkan pada prinsip-prinsip agama Hindu dan Buddha. Contoh apabila melihat pada beberapa objek candi, dapat ditemukan ornamen yang hanya terdapat di bagian tertentu saja, antara kepala, badan, kaki, maupun keduanya bahkan pada seluruh elemen candi. Perletakan ornamen tersebut pun menghasilkan makna yang spesifik, perbedaan penempatan ornamen akan mengakibatkan perbedaan makna pula. Perwujudan bentuk ornamen pun dapat berbeda secara fisik, ditinjau dari era klasik tua, klasik tengah dan klasik muda. Perubahan wujud fisik tersebut bisa saja dapat merubah makna sebelumnya atau bisa juga memiliki makna yang tetap atau sama.

Melalui latar belakang ini, penelitian difokuskan kepada bagaimana makna ornamen pada bangunan candi Hindu dan Buddha di pulau Jawa. Penelitian yang dilakukan bersifat kualitatif, dengan menggunakan metode analisis deskriptif. Analisa dilakukan dengan melakukan pematriksan antara objek studi dengan teori dan prinsip, akan menghasilkan jawaban bagaimana perletakan ornamen pada elemen candi dan apa makna yang terkandung didalamnya, juga perubahan wujud fisik bentuk ornamennya.

Objek studi penelitian yang digunakan adalah candi candi peninggalan Hindu dan Buddha yang berada di pulau Jawa, dengan objek penelitian: Candi Arjuna (Dieng), Candi Bima (Dieng), 
Candi Blandongan (Batujaya), Candi Siwa (Prambanan), Candi Ijo, Candi Borobudur, Candi Kalasan, Candi Penataran, Candi Kidal, Candi Jago, dan Candi Cetho.

\section{TEORI ORNAMEN DALAM ARSITEKTUR CANDI}

Ornamen berasal dari kata Ornare (bahasa Latin) yang berarti menghiasi. Ornamen merupakan karya seni yang sengaja dibuat untuk menambah nilai estetis dari suatu benda dengan tujuan untuk menambah nilai finansial dari benda tersebut.

Ornamen terbagi menjadi enam motif: (1) Motif Geometris. Motif tertua dari ornamen adalah bentuk geometris, memanfaatkan unsur-unsur dalam ilmu ukur seperti garis-garis lengkung dan lurus, lingkaran, segitiga, segiempat, bentuk meander, swastika, dan lain-lain. (2) Motif Floral.PengFiguran motif tumbuh-tumbuhan dapat diwujudkan baik dengan gaya natural maupun stilirisasi, jenis tumbuhan yang dijadikan obyek juga berbeda tergantung dari lingkungan tempat motif tersebut diciptakan. (3) Motif Fauna. Penggambaran binatang dalam ornamen sebagian besar merupakan hasil gubahan/stilirisasi, namun masih dikenali bentuk dan jenis binatangnya. Dalam visualisasinya bentuk binatang terkadang hanya diambil pada bagian tertentu (tidak sepenuhnya) dan dikombinasikan dengan motif lain.

(4) Motif Manusia.Manusia sebagai salah satu obyek dalam penciptaan motif ornamen mempunyai beberapa unsur, baik secara terpisah seperti kedok atau topeng, dan secara utuh seperti bentuk-bentuk dalam pewayangan. Dikatakan motif manusia karena dalam pembuatan ragam hiasnya mengacu pada figure manusia. (5) Motif Kosmos. Motif kosmos atau berbentuk alam dalam penciptaannya digubah sedemikian rupa menjadi suatu motif dengan karakter tertentu sesuai dengan sifat benda yang diekspresikan. Dikatakan motif kosmos atau alam memang dalam pembuatannya mengacu pada bentuk-bentuk alam, seperti: awan, cadas, air, batu, gunung, dsb. (6) Motif Kreasi/ Khayalan. Bentuk ragam hias kreasi merupakan hasil daya dan imajinasi manusia atas persepsinya, motif mengambil sumber ide diluar dunia nyata (contoh makhluk gaib).

Ornamen sebagai ragam hias simbolis, selain mempunyai fungsi sebagai penghias suatu benda juga memiliki nilai simbolis tertentu di dalamnya. Bentuk, motif dan penempatannya sangat ditentukan oleh norma-norma tertentu terutama norma agama yang harus ditaati, untuk menghindari timbulnya salah pengertian akan makna atau nilai simbolis yang terkandung didalamnya.

Teknik perwujudan atau penggambaran ornamen dapat terbagi tiga: Realis atau naturalis yaitu pembuatan motif ornamen yang berusaha mendekati atau mengikuti bentukbentuk secara alami tanpa melalui suatu gubahan. Stilirisasi atau gubahan yaitu pembuatan motif ornamen dengan cara melakukan gubahan atau merubah bentuk tertentu, dengan tidak meninggalkan identitas atau ciri khas dari bentuk yang digubah/distilirisasi. Kombinasi atau kreasi yaitu motif yang dibuat dengan mengkombinasikan beberapa bentuk atau motif, yang merupakan hasil kreasi dari senimannya. Motif yang tercipta dengan cara ini biasanya mewakili karakter atau identitas individu penciptanya (idealisme).

Ornamen ada yang bersifat pasif dan aktif. Pasif yakni ornamen tersebut hanya berfungsi menghias saja (estetis), tidak ada kaitanya dengan hal lain seperti ikut mendukung konstruksi atau kekuatan suatu benda. Sedangkan ornamen berfungsi aktif yakni selain untuk menghias suatu benda juga mendukung hal lain pada benda tersebut seperti menentukan kekuatannya (struktural). 


\subsection{KARAKTERISTIK ARSITEKTUR CANDI HINDU DAN BUDDHA SERTA PERIODISASI CANDI}

Dalam perancangannya, arsitektur Hindu menggunakan mandala sebagai dasar pembangunan bangunannya. Menurut Rahadhian (1999), mandala dianggap sebagai model mikrokosmos, manifestasi dari makrokosmos yang transedental. Mandala dianggap sebagai model dari pusat dunia atau "imago mundi" dan bangunan yang didirikan diatasnya dianggap sebagai "axis mundi". Axis mundi adalah tiang penghubung antara tiga alam yaitu alam bawah, tengah, dan atas. Dan dalam prakteknya, axis mundi ini diwujudkan dengan bangunan suci, dimana axis mundi diwujudkan dengan bangunan suci kuil yang tinggi seperti tiang yang menghubungkan alam bawah dengan alam atas.

Dalam ajaran Hindu, alam dibagi menjadi 3 bagian yaitu Bhurloka, Bhuvarloka, dan Swarloka. Tiang penghubung (axis mundi) menjadi penghubung dari ketiga alam tersebut, dan Gunung Meru menjadi abstraksi dari penghubung ketiga alam tersebut.

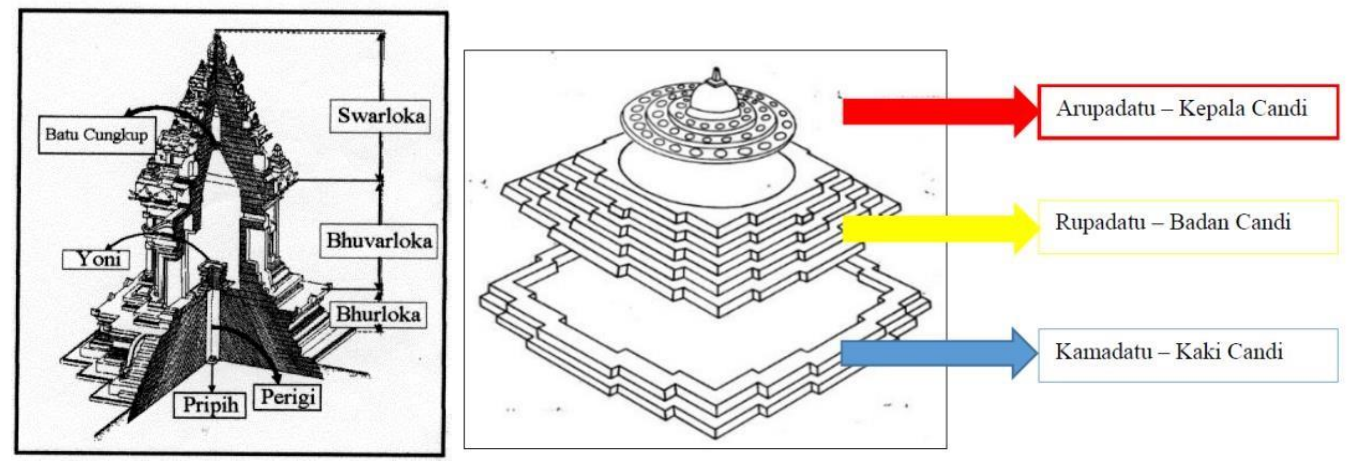

Figur 1. Pembagian 3 dunia pada candi dalam ajaran Hidnu dan Buddha

Sedangkan dalam ajaran Buddha dikenal tiga unsur berbeda yaitu tubuh, ucapan dan pikiran. Selain itu kehidupan alam semesta ini juga biasanya diperlihatkan di dalam candi yang terbagi menjadi tiga yaitu Kamadatu, Rupadatu dan Arupadatu.

Kamadatu merupakan bagian kaki pada candi, merepresentasikan kehidupan manusia pada semesta ini. Manusia pada bagian ini masih memiliki hawa nafsu dan belum bertekad untuk mencapai pencerahan atau keempurnaan

Rupadatu merupaan bagian badan pada candi, merepresentasikan kehidupan manusia yang telah bertekad untuk mencapai Kebuddha-an. Manusia pada bagian ini mulai belajar dan menghentikan semua hawa nafsu mereka demi pencapaian kesempuranaan.

Arupadatu merupakan bagian kepala pada candi, dianggap sebagai kehidupan dewa, Boddhisatwa dan Buddha. Tingkatan ini merupakan tingkatan paling suci dan semua hawa nafsu yang ada sudah dihilangkan secara total.

Mengutip buku Kajian Tipo Morfologi Arsitektur Candi di Jawa, Rahadhian Prajudi H (1999), candi dapat diklasifikasikan berdasarkan periode pembangunannya sebagai berikut: (1) Periode Awal (Klasik Tua) berkisar (-800 M) (2) Periode Tengah (Klasik Utama) berkisar (8001200 M) (3) Periode Akhir (Klasik Muda) berkisar (1200-1400 M). 


\section{PEMBAHASAN MAKNA ORNAMEN DALAM ARSITEKTUR CANDI}

\subsection{MOTIF GEOMETRIS}

\subsubsection{PERSEGI DAN LINGKARAN}

Di dalam Satapatha Brahmana (Hindu) menyatakan bahwa persegi melambangkan surgawi dan lingkaran melambangkan duniawi. Persegi bersifat statis, stabil, tidak Mudah bergerak dan berubah, hal ini melambangkan surga yang kekal. Tetapi di dalam pandangan Buddha, hidup merupakan proses dari 'roda dharma' yang terus berputar. Jadi lingkaran melambangkan sesuatu yang tidak ada awal dan akhir, suatu proses yang berjalan terus menerus, bersifat trandesendental dan abstrak.

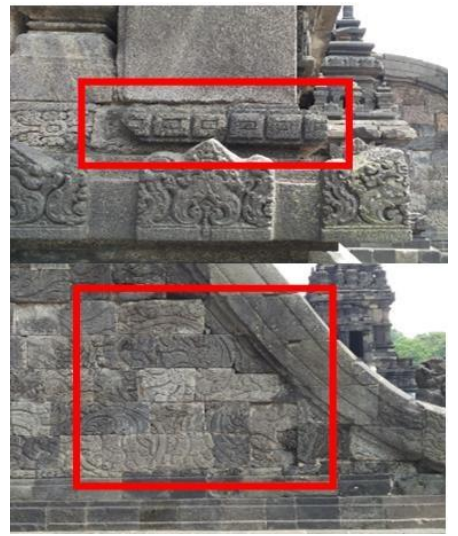

Figur 2. Salah satu contoh motif geometrik persegi dan lingkaran pada Candi Siwa Prambanan

Motif persegi hampir ditemukan pada seluruh era Klasik: Klasik Tua, Klasik Tengah, dan Klasik Muda. Ragam bentuk persegi pun berbeda-beda pada setiap era, seperti motif persegi pada Candi Bima (Klasik Tua), Candi Prambanan (Klasik Tengah), dan Candi Angka Tahun Penataran (Klasik Muda). Motif persegi dapat terwujud kedalam berbagai rupa, antara lain motif berbentuk persegi panjang, untaian bentuk persegi seperti kalung, dan lain-lain. Ornamen ini ada yang bersifat estetis dan struktural.

Motif lingkaran ditemukan pada era Klasik Tengah, dan Klasik Muda. Contoh motif lingkaran terdapat pada Candi Ijo dan Candi Kidal. Bentuk lingkaran dapat terwujud kedalam berbagai rupa juga, seperti motif bunga dalam lingkaran (bunga ceplok), sulur-suluran yang melingkar, dan lain sebagainya. Ornamen ini ada yang bersifat estetis dan struktural.

\subsubsection{MEANDER}

Meander merupakan suatu pola ragam hias menyerupai huruf T, dibuat tegak dan terbalik, disusun berselang-seling. Meander umum ditemukan dalam seni Tionghoa. Bentuk meander dapat berbentuk melengkung menyerupai bentuk 'pinggir awan'. Meander sering diartikan sebagai motif kain, maupun dunia bawah. Motif meander baru ditemukan pada candi di klasik muda, salah satunya yakni pada candi Jago. Motif meander bersifat estetis, digunakan sebagai penghias bidang dinding pada kaki candi Jago. 


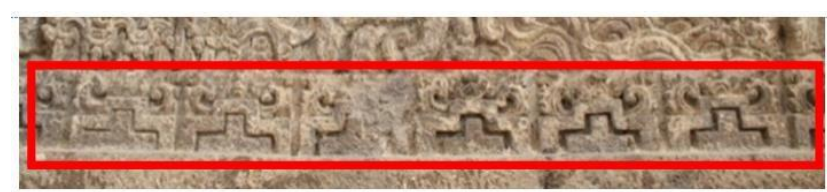

Figur 3. Motif Meander pada Relief Candi Jago

\subsubsection{TUMPAL}

Pinggir-tumpal adalah suatu pola hias berbentuk deretan segitiga-segitiga sama kaki, Tumpal seringkali dihiasi dengan ragam hias sulur-suluran. Motif ini melambangkan kesuburan.

Motif Tumpal ditemukan menghiasi elemen candi pada zaman Klasik Tengah dan Klasik Muda. Motif Tumpal pada elemen candi bersifat sebagai estetis. Contoh terdapat pada candi Penataran (Candi Angka Tahun), candi Kidal dan candi Jago. Motif tumpal muncul pada zaman Klasik Muda karena pada saat itu, masyarakat jawa khususnya jawa timur sedang memasuki tren membatik. Tidak hanya pada kain, motif batik ini diimplementasikan pula kepada candi sebagai bangunan suci pada kerajaan Hindu - Buddha.

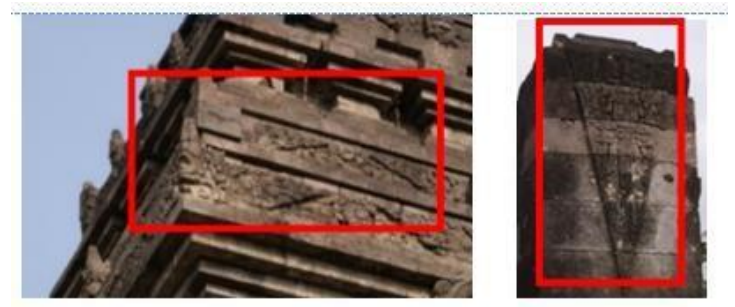

Figur 4. Motif tumpal pada kepala candi Kidal dan 'Lidah Tangga' Candi Penataran

\subsubsection{KERTAS TEMPEL}

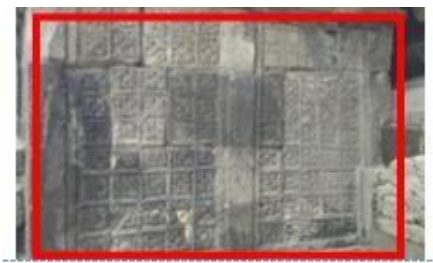

Figur 5. Motif Kertas Tempel pada dinding Candi Siwa Penataran

Motif kertas tempel atau ceplokan merupakan ragam hias yang terdiri atas satu motif dan disusun berulang-ulang. Motif kertas tempel digunakan untuk menghiasi bidang dinding.

Motif Kertas tempel muncul pada era Klasik Tengah, yakni pada Candi Siwa Prambanan, dan Candi Pewara pada candi Ijo. Motif kertas tempel berbentuk seperti kertas yang didalamnya dihiasi dengan elemen ornamen lain, seperti bunga kecil diletakkan berurutan. Fungsi nya sebagai hiasan estetis saja. Tidak ada perkembangan wujud karena motif ini muncul pada satu era Klasik saja.

\subsubsection{PROFIL MOULDING}




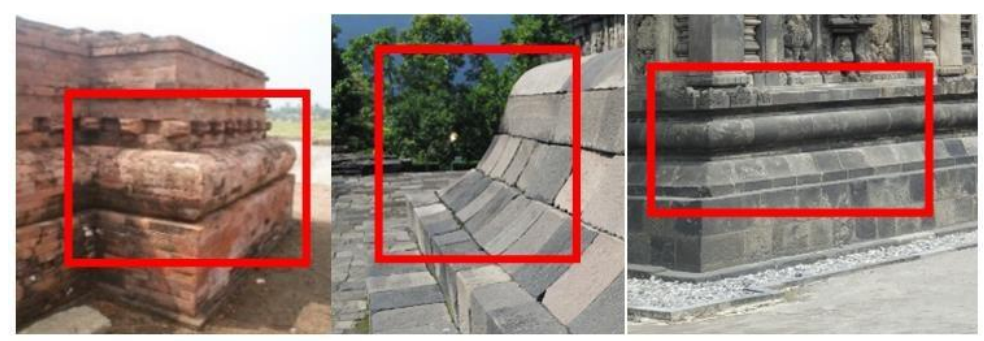

Figur 6. Profil Moulding pada Candi Blandongan, Candi Borobudur, dan Candi Siwa Prambanan

Profil ditemukan pada seluruh candi Hindu-Buddha di pulau Jawa. Profil moulding bersifat struktural. Terdapat berbagai macam tipe profil, seperti pelipit pada candi Arjuna,

Mustili Bandha pada candi siwa prambanan, Padma pada candi Borobudur, dan lain-lain. Umumnya profil seperti Kumuda, Padma, dan profil lainnya yang mengandung unsur melengkung mencirikan candi Buddha (Candi Borobudur, Candi Kalasan)

Terdapat suatu kesamaan rupa pada masing-masing era. Klasik Tua memiliki bentuk profil yang lebih polos (contoh: bidang rata, pelipit), dengan minim ragam hias menghiasi profil, dan proporsi profil agak meliuk namun kaku. Klasik Tengah memiliki bentuk profil yang ramai (contoh: pelipit, kumuda, Padma, dll), terdapat berbagai macam ragam hias dan memiliki kesan bentuk yang tambun dan kokoh. Klasik Muda memiliki bentuk profil yang setipe namun berlapis banyak (contoh: pelipit saja), dihiasi ragam hias yang cukup (tidak seramai pada era Klasik Tengah), dan memiliki proporsi bentuk yang lebih ramping dan tinggi serupa dengan proporsi candi.

\subsection{MOTIF FLORAL}

\subsubsection{KALPATARU-KINARA-KINARI}

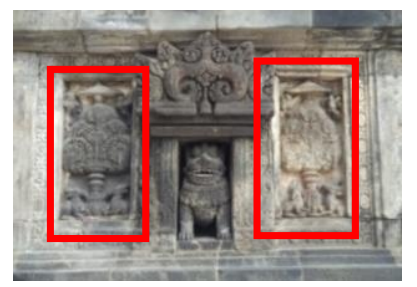

Figur 7. Motif sepasang Kalpataru-kinara-kinari pada kaki Candi Siwa, Prambanan

Kalpataru atau Kalpawrksa adalah pohon kahyangan, hidup sepanjang masa, tempat menggantungkan segala asa. Dijaga oleh makhluk kahyangan Kinara - Kinari, berwujud setengah manusia setengah burung.

Kalpataru-Kinara-Kinari hanya muncul pada era Klasik Tengah, yakni pada Candi Siwa Prambanan. Yang menarik ialah mengapa penggambaran pohon dan makhluk kahyangan ditempatkan pada bagian bawah candi yang melambangkan dunia bawah? Menurut Prof. Hariani Santiko, perwujudan candi diibaratkan sebagai posisi bermeditasi. Penempatan ornamen tersebut diletakan pada titik titik 'nadi cakra', pada titik hati. Energi dari bawah kemudian tersalurkan keatas seperti saat sedang bermeditasi. Penggambaran Kalpataru dapat dimaksudkan sebagai penggambaran dunia atas (surga) di dunia bawah, sehingga manusia pada dunia bawah dapat melihat dan memahami bagaimana kehidupan di dunia atas. 


\subsubsection{PURNAKALASA}

Di India, motif Purna-kalasa merupakan ragam hias yang sangat indah, berbagai bunga dan daun-daunan keluar dari Jambangan memiliki nilai simbolik sebagai lambang kesuburan dan kemakmuran, berkaitan dengan dewa kuwera, dalam mitologi Hindu merupakan dewa kekayaan.

Purnakalasa terdapat pada masing-masing era: Klasik Tua, Klasik Tengah, dan Klasik Muda. Penempatan ornamen purnakalasa tidak mengikat pada pembagian kepala, badan dan kaki candi, tetapi lebih mengindikasikan lambang kemakmuran dan kekayaan.

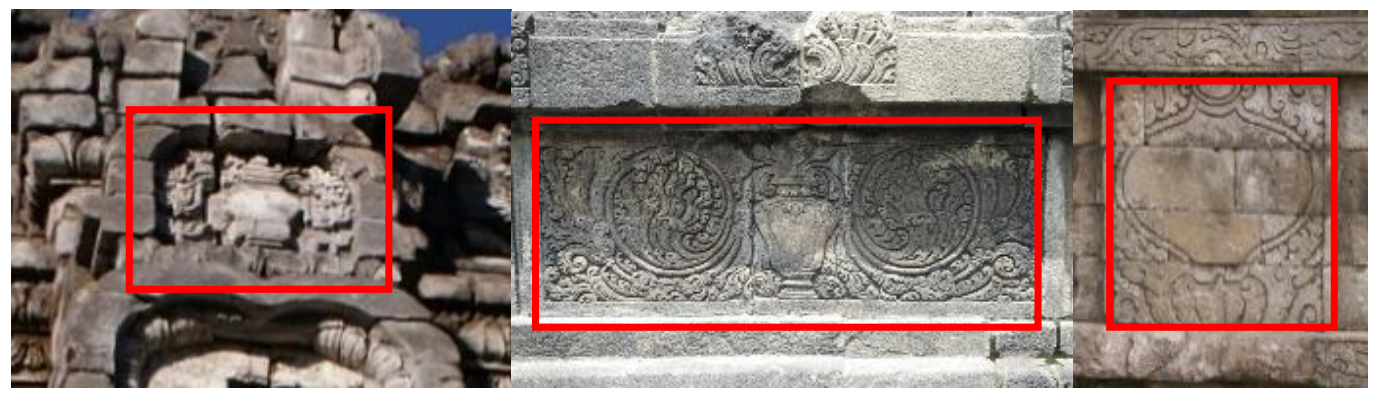

Figur 8. Ornamen Purnakalasa pahat timbul pada Candi Bima, Purnakalasa pahat timbul tipis pada Candi Siwa Prambanan, dan Purnakalasa pahat ukir pada Candi Kidal

\subsubsection{TERATAI}

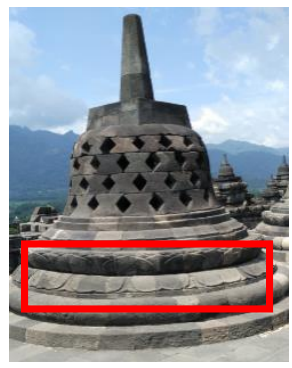

Figur 9. Motif bunga Teratai pada dasar stupa Candi Borobudur

Bunga teratai adalah bunga nasional di India, dianggap sebagai simbol dari Kebenaran, Kesucian dan Keindahan. Konon Buddha digambarkan duduk di atas bunga teratai raksasa. Motif teratai hanya ditemukan pada era Klasik Tengah, khususnya pada candi Buddha yakni candi Borobudur dan candi Kalasan, dimana motif teratai menghiasi stupa pada candi. Motif teratai wajib berada pada bagian kaki stupa, hal ini mengacu pada ajaran Buddha dimana stupa digambarkan sebagai posisi Buddha bermeditasi diatas bunga teratai. Bentuk teratai dipahatkan sesuai dengan bentuk aslinya (naturalis).

\subsubsection{BUNGA}




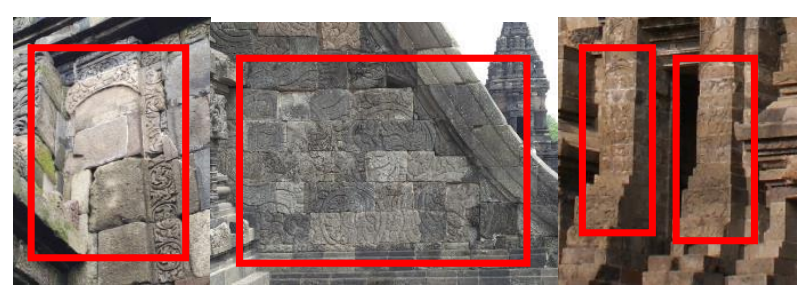

Figur 10. Motif Bunga dalam Lingkaran pada Candi Ijo, Candi Siwa Prambanan dan Candi Kidal

Motif bunga dapat menggambarkan keindahan alam sekitarnya, juga melambangkan rasa seni dan keharuman khas bunga. Motif bunga biasanya dipadukan dengan bentuk geometrik dasar.

Motif bunga tidak ditemukan pada candi Klasik Tua, baru muncul pada candi Klasik Tengah dan Muda. Antara candi Hindu maupun Buddha tidak terdapat perbedaan makna, yakni menggambarkan keindahan alam sekitarnya. Motif bunga selalu hadir pada badan bangunan, dan beberapa ditemukan pada kaki dan kepala candi. Motif bunga bersifat sebagai elemen estetis penghias permukaan dinding candi.

\subsubsection{SULUR-SULURAN}

Motif sulur-suluran (sulur dedaunan) melambangkan kehidupan yang bertumbuh, lambang kesuburan, kemakmuran, dan alam semesta. Motif sulur suluran hampir ditemukan pada seluruh objek candi. Sulur-suluran tidak hanya berdiri sendiri, namun dapat juga berfungsi sebagai penghias ornamen lainnya seperti antefix, stirilisasi kepala kala, dan lainlain.

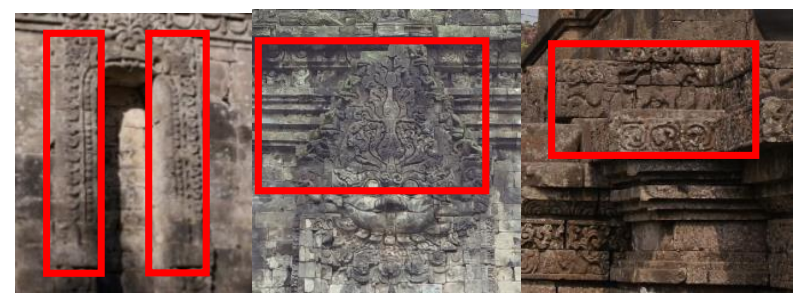

Figur 11. Motif sulur-suluran pada Candi Arjuna, Candi Kalasan, dan Candi Jago.

\subsection{MOTIF FAUNA}

\subsubsection{AMPHIBI: KURA-KURA}

Ornamen berupa arca kura-kura ditemukan pada candi Cetho di era Klasik Muda. Terletak di aras ketiga, ornamen ini melambangkan penciptaan alam semesta. Ornamen ini digabungkan dengan ornamen alat genital manusia (penis) sebagai perlambang penciptaan manusia.

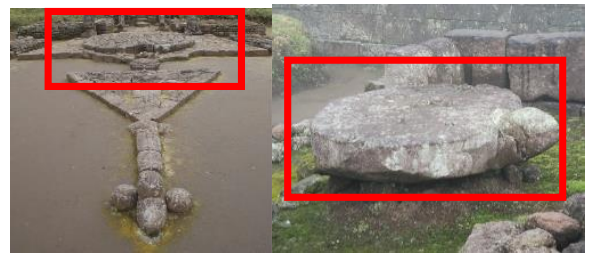

Figur 12. Ornamen Kura-kura berbentuk arca setengah badan pada Candi Cetho

\subsubsection{AVES: BURUNG, GARUDA}


Ornamen berupa burung ditemukan pada kaki candi Siwa Prambanan dan kepala candi Ijo. Motif burung menyatu dengan motif guirlande, kalpataru, dan ornamen - ornamen lainnya. Fungsinya hanya sebagai elemen estetis saja, untuk menghiasi permukaan dinding candi.

Ornamen berupa Garuda ditemukan pada Candi Penataran. Ornamen berupa fragment Garuda ditemukan di dinding kaki menjadi bagian dari narasi yang terkandung dalam relief di sepanjang dinding Candi Penataran.

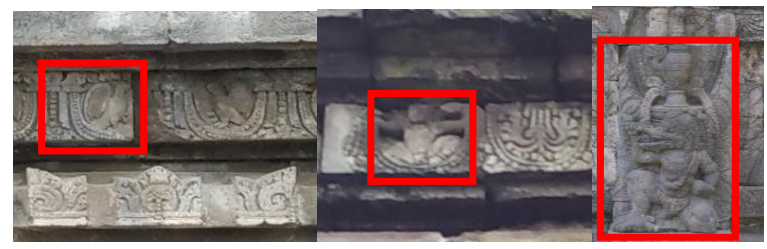

Figur 13. Motif Burung pada Candi Prambanan dan Candi Ijo, dan Motif Garuda pada Candi Kidal

\subsection{MAMALIA: SINGA}

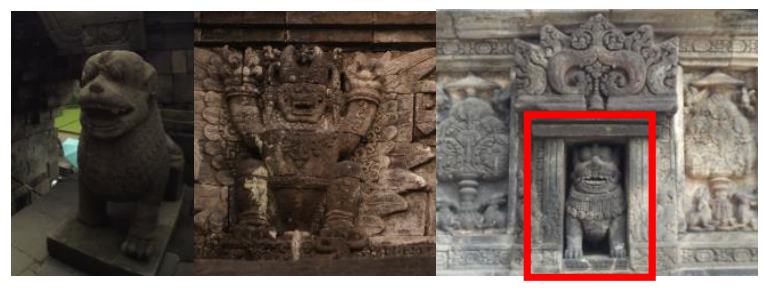

Figur 14. Ornamen Singa pada Candi Borobudur, Candi Induk Penataran, dan Candi Prambanan

Patung Singa merupakan simbol dari keberanian, kebijaksanaan, dan kekuasaan. Dalam ajaran agama Buddha motif hiasan singa dapat dihubungkan maknanya dengan sang Buddha. Julukan "Singa dari keluarga Sakya" serta ajaran yang disampaikan oleh sang Buddha juga diibaratkan sebagai suara atau Simhanada yang terdengar keras di seluruh penjuru mata angin.

Ornamen ini dapat ditemukan pada Candi Borobudur, Candi Penataran, dan Candi Jago. Namun ditemukan juga pada candi Hindu Prambanan, satu kombinasi dengan Motif Prambanan. Hal ini dapat mengindikasikan bahwa pada candi Hindu dapat dipengaruhi oleh motif Buddha.

\subsubsection{REPTIL: ULAR}

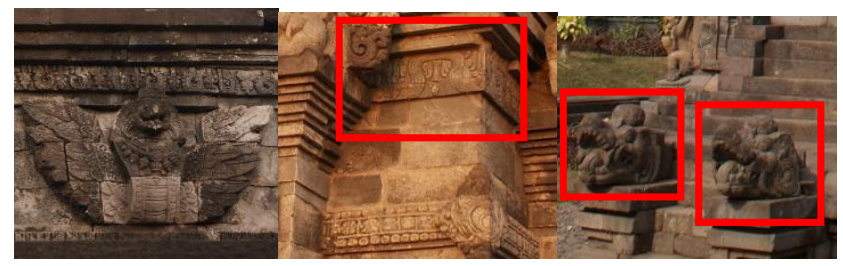

Figur 15. Ornamen Ular pada Candi Penataran, Candi Angka Tahun Penataran, dan Candi Kidal

Menurut tradisi, ular termasuk hewan suci yang dipuja-puja oleh kelompok masyarakat Dravidia di India. Karena kepercayaan ini maka pada awal kebangkitannya kesenian yang bercorak Buddhis semua bangunannya dihias dengan ular dan juga yaksha (raksasa penjaga candi).

Ornamen ular baik berupa fragment dari sebuah narasi, maupun motif bentuk ular muncul pada zaman klasik Muda. Kemunculan ornamen ular pada zaman klasik Muda dikarenakan 
kepercayaan masyarakat yang menganggap ular merupakan penjelmaan dari dewa air, penguasa dunia bawah. Ornamen ini ditemukan pada candi Penataran, baik pada Candi Induk nya maupun pada Candi Angka Tahun, dan candi Kidal.

\subsection{MOTIF MANUSIA}

\subsubsection{ALAT GENITAL MANUSIA}

Ornamen berupa alat genital manusia (phallus) ditemukan pada candi Klasik Muda, khususnya pada Candi Cetho. Ornamen ini diletakkan secara horizontal (pada bidang tanah), berbeda dengan candi Sukuh, yang diletakkan vertikal, membentuk sebuah arca manusia dengan posisi sedang memegang phallus yang berdiri. Meskipun berbeda perwujudannya, makna yang terkandung didalamnya tetap sama, yakni sebagai perwujudan manusia di alam semesta.

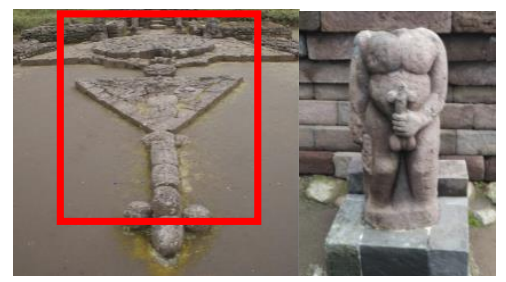

Figur 16. Ornamen berupa Phallus pada Candi Cetho, dan Arca Manusia pada Candi Sukuh

\subsection{MOTIF KOSMOS \\ 3.5.1 KEPALA KALA}

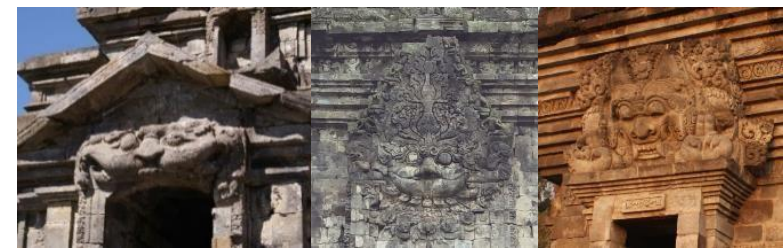

Figur 17. Ornamen Kepala Kala Pada Candi Arjuna, Candi Kalasan, dan Candi Angka Tahun Penataran

Kirtimukha biasanya diletakkan di depan gerbang utama atau pintu masuk dari candi. Memiliki tujuan sebagai penjaga gerbang dan mengusir makhuk jahat. Dalam ajaran agama Hindu, Kala adalah putera Dewa Siwa yang bergelar sebagai dewa penguasa waktu. Kala merupakan simbol bahwa siapa pun tidak dapat melawan hukum karma. Apabila sudah waktunya seseorang meninggalkan dunia fana, maka pada saat itu pula Kala akan datang menjemputnya.

Kepala kala bersifat struktural, merupakan bagian dari struktur pintu pada candi. Kepala Kala pada era Klasik Tua dan Klasik Tengah memiliki ekspresi yang lebih ramah dan menunjukan mimik wajah yang tersenyum, berbeda dengan Kepala Kala pada era Klasik Muda yang lebih seram dan menakutkan. Hal ini diakibatkan pengaruh India pada Klasik Tua dan pengaruh kerajaan Mataram pada Klasik Tengah mengakibatkan Kepala Kala berekspresi ramah, sedangkan pada Klasik Muda dipengaruhi oleh Hindu Tantra dan Majapahit yang lebih ekspresif, dramatis dan puitik (bukan naturalis) dalam pembuatan ornamen.

\subsubsection{MAKARA}




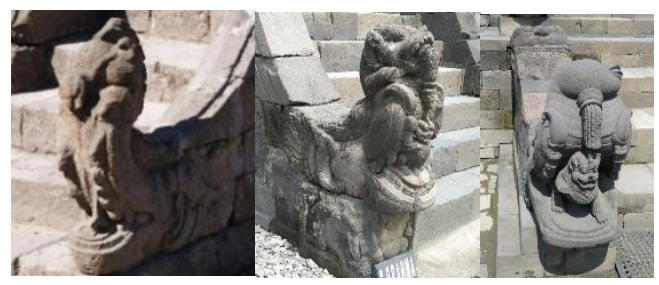

Figur 18. Ornamen Makara pada Candi Arjuna, Candi SIwa Prambanan, dan Candi Borobudur.

Makara merupakan monster laut atau penguasa laut dalam istilah Sanskrit yang biasa diidentifikasi sebagai dua hewan gabungan: di bagian depan berwujud binatang seperti gajah atau buaya, di bagian belakang digambarkan sebagai hewan air di bagian ekor seperti ikan atau naga.

Makara ditemukan pada candi era Klasik Tua dan Klasik Tengah. Candi Arjuna, Candi Prambanan, Candi Ijo, Candi Borobudur, dan Candi Kalasan ditemukan Makara, baik sebagai pinggir anak tangga maupun pada pinggir pintu masuk candi, satu kesatuan dengan kepala kala. Makara bersifat struktural, karena merupakan bagian pada anak tangga candi dan struktur pintu masuk candi.

\subsubsection{ARCA DEWA (RELUNG - RELIEF)}

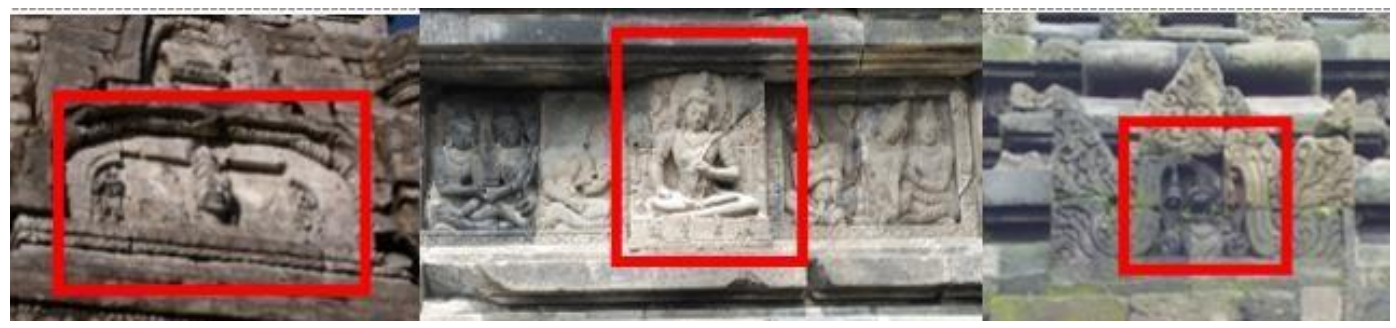

Figur 19. Arca Dewa pada Relung Candi Bima, Relief Candi Siwa Prambanan, dan Antefix Candi Ijo

Arca adalah patung yang dibuat dengan tujuan utama sebagai media keagamaan, yaitu sarana dalam memuja tuhan atau dewa-dewinya. Arca berbeda dengan patung pada umumnya, yang merupakan hasil seni yang dimaksudkan sebagai sebuah keindahan.

Perletakan ornamen arca Dewa pada objek candi didapati berbeda-beda, yakni pada elemen kaki, badan, kepala, pada kedua bagian maupun seluruh elemen candi. Dapat dikatakan, perletakan ornamen tidak didasarkan pada pembagian tiga dunia (dunia atas, dunia tengah, dunia bawah), melainkan dikhususkan pada arah mata angin dan orientasi gunung. Arca Dewa dan Buddha bersifat sebagai elemen estetis, namun memiliki makna yang suci, sehingga wajib hadir pada setiap elemen candi.

\subsubsection{KALA SUDUT}

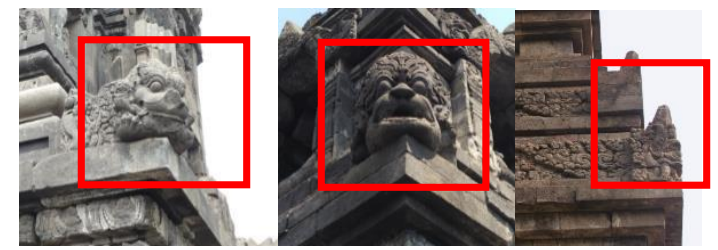

Figur 20. Ornamen Kala Sudut pada Candi Siwa Prambanan, Candi Borobudur, dan Candi Kidal 
Sama seperti makna dari Kala yakni untuk mengusir roh-roh jahat, hanya penempatannya dikhususkan untuk menghiasi sudut-sudut pada candi. Kala sudut sebenarnya dapat dikatakan antefix yang digabung / dihiasi dengan kala.

Kala sudut mulai ditemukan pada era Klasik Tengah dan Klasik Muda. Perletakan di sudut candi dimaksudkan agar kala menjaga kesucian candi tidak hanya dari pintu masuk saja, tetapi melindungi seluruh sudut candi. Kala sudut bersifat sebagai ornamen estetis, bukan struktural.

\subsubsection{JALADWARA}

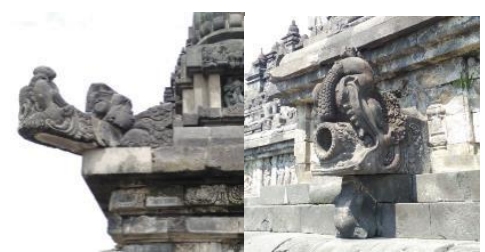

Figur 21. Ornamen Jaladwara pada Candi Siwa Prambanan dan Candi Borobudur

Dalam mitologi Hindu, Jaladwara berarti ikan, melukiskan mulut ikan yang menghadap ke luar candi. Wujud fisiknya menyerupai makara, namun terdapat lubang saluran air. Jaladwara berfungsi untuk mengalirkan air hujan dari kaki candi ke luar candi.

Ornamen ini ditemukan pada candi Klasik Tengah, khususnya pada candi yang terdapat pelataran atau selasar, yakni pada Candi Prambanan dan Candi Borobudur. Berbentuk makara, dimaksudkan juga sebagai pengusir roh jahat atau energi negatif. Ornamen ini bersifat struktural, karena fungsinya sebagai struktur saluran keluarnya air hujan.

\subsubsection{KEMUNCAK}

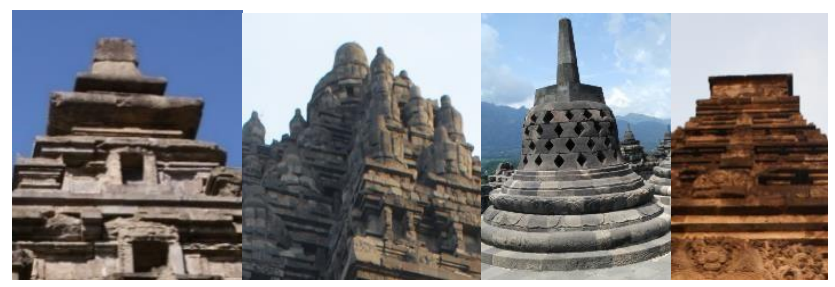

Figur 22. Kemuncak berupa Kalasa - Ratna - Stupa - Kubus

Kemuncak merupakan bagian tertinggi dari sebuah candi. Kemuncak menggambarkan ranah surgawi tempat para dewa dan jiwa yang telah mencapai kesempurnaan bersemayam. Kemuncak dapat berupa stupa, ratna, wajra, atau lingga semu.

Kemuncak stupa hanya ditemukan pada candi beraliran agama Buddha, kemuncak ratna dan kalasa ditemukan pada candi beraliran agama Hindu, sedangkan kemuncak kubus hanya ditemukan pada candi era Klasik Muda. Masing- masing kemuncak memiliki makna masingmasing, namun secara keseluruhan, kemuncak merupakan bagian paling suci dalam candi.

\subsubsection{GANA}




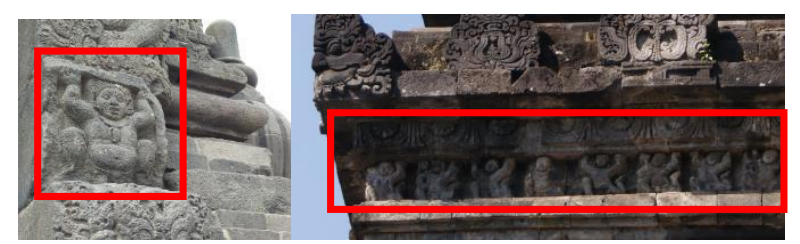

Figur 23. Ornamen Gana berwujud manusia kerdil pada Candi Siwa Prambanan dan Candi Borobudur

Relief gana digambarkan dengan sikap khas, yakni posisi tangan menyangga, naturalis, ekspresi biasa, tersenyum atau marah, alat kelamin tidak diperlihatkan.

Motif Gana ditemukan pada candi era Klasik Tengah, terdapat pada Candi Prambanan, Candi Borobudur, dan Candi Kalasan. Gana yang merupakan armada perang dewa Siwa berwujud seperti manusia kerdil. Perwujudannya dengan proporsi tubuh utuh, dengan teknik pahat timbul.

\subsection{MOTIF KREASI}

\subsubsection{ANTEFIX}

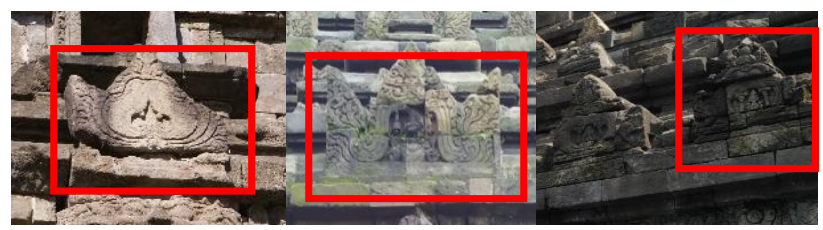

Figur 24. Ornamen Antefix pada Candi Arjuna, Candi Ijo, dan Candi Borobudur

Antefix merupakan hiasan 'mahkota' segitiga (tumpal berjajar tiga) pada bagian puncak dinding, berhias dewa dan motif sulur-suluran. Antefix biasanya diletakkan di perbatasan atau lis yang memisahkan antara bagian candi. Antefix dibuat untuk memberi kesan bangunan lebih tinggi daripada biasanya.

Antefix ditemukan pada beberapa candi pada era Klasik Tua, Klasik Tengah, dan Klasik Muda, antara lain Candi Arjuna, Candi Prambanan, Candi Ijo, Candi Borobudur, Candi Kalasan, dan Candi Kidal. Khusus pada candi Buddha seperti Candi Borobudur dan Candi Kalasan, antefix tidak digunakan pada elemen kepala candi, melainkan menggunakan bentuk stupa.

\subsubsection{RELIEF NARATIF}

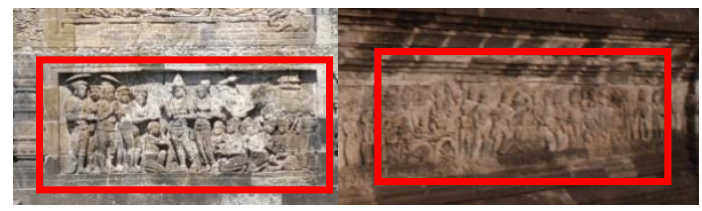

Figur 25. Ornamen Relief Naratif pada Candi Borobudur dan Candi Penataran

Relief adalah seni pahat dan ukiran 3-dimensi yang biasanya dibuat di atas batu. Relief membentuk suatu seri cerita atau ajaran. Jenis relief yang digunakan pada candi yakni relief rendah, ukiran sedikit menonjol dari dasar permukaan dinding. Relief narasi biasanya ditemukan pada dinding candi yang memiliki selasar di dalamnya, seperti Candi Prambanan, Candi Borobudur, 
Candi Penataran, dan Candi Jago. Relief narasi pada masing-masing candi memiliki cerita tersendiri. Relief narasi bersifat sebagai elemen estetis, berfungsi sebagai hiasan pada dinding candi.

\subsubsection{MEDALLION}

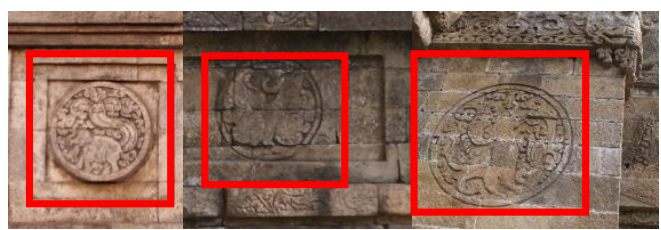

Figur 26. Ornamen Medallion pada Candi Penataran dan candi Kidal

Medallion berupa ukiran berbentuk sebuah lingkaran, didalamnya dapat dihiasi dengan ornamen lain maupun relief cerita. Diperkirakan medallion muncul akibat pengaruh Cina yang menyebarluas, mempengaruhi kerajaan jaman klasik muda (Singosari dan Majapahit).Ornamen medallion hanya ditemukan pada candi era Klasik Muda, seperti pada Candi Penataran dan Candi Kidal. Motif medallion bersifat sebagai elemen estetis.

\subsubsection{TIRAI}

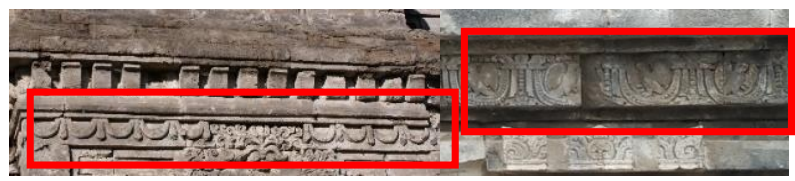

Figur 27. Motif Guirlande pada Candi Bima dan Candi Prambanan

Guirlande adalah motif hiasan berbertuk untaian, berfungsi sebagai hiasan, juga untuk memberi kesan agar kamar candi tidak terlalu kosong atau nampak terlalu tinggi. Motif Ornamen Guirlande ditemukan pada era Klasik Tua, Klasik Tengah, dan Klasik Diperkirakan penggambaran tirai mengindikasikan suasana kebudayaan masyarakat saat itu dimana pendopo atau keraton dihiasi dengan kain semacam tirai untuk memperindah bangunan. Motif ini bersifat sebagai estetis, diukir pada dinding candi.

\subsubsection{PILASTER}

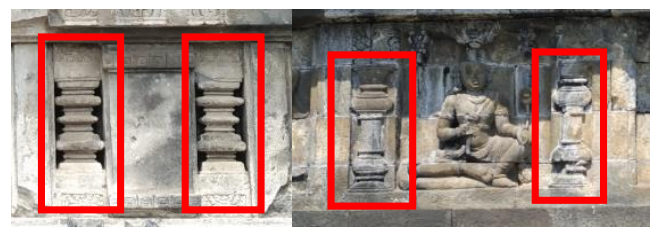

Figur 28. Ornamen Pilaster pada Candi Prambanan dan Candi Borobudur

Pilaster merupakan motif berupa tiang atau kolom. Pilaster dapat mengartikan kesan struktural pada candi, menahan beban atau menyanggah suatu ornamen lain di atasnya. Pilaster 
biasa ditemukan pada kaki candi, dan berhubungan dengan ornamen lain. Motif Pilaster ditemukan pada era Klasik Tua, Klasik Tengah, dan Klasik Muda, antara lain Candi Bima, Candi Prambanan, Candi Borobudur, Candi Kalasan, dan Candi Kidal. Ornamen ini dikategorikan sebagai elemen estetis, meskipun memberikan kesan struktural.

\subsection{6 'LIDAH TANGGA'}

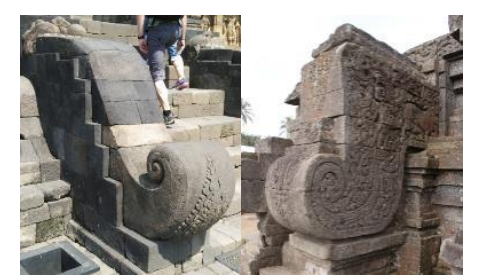

Figur 29. Ornamen ‘Lidah Tangga’ pada Candi Borobudur dan Tangga Sulur pada Candi Jago

'Lidah Tangga' atau tangga berbentuk sulur merupakan jenis lain dari Makara, fungsinya sama yakni sebagai pinggiran anak tangga. Motif 'Lidah Tangga' ditemukan pada candi di era Klasik Tengah dan Klasik Muda, seperti pada Candi Borobudur, Candi Penataran, Candi Kidal dan Candi Jago. Disebut lidah karena pada bagian atas terdapat ornamen kepala kala, dimana sepanjang anak tangga berbentuk meliuk layaknya bentuk lidah Sedangkan tangga suluran berbentuk seperti lidah, namun telah distilir, dihiasi dengan motif tumpal dan sulur-suluran.

\subsubsection{SABUK}

Sabuk berfungsi untuk mengurangi kesan vertikal pada bangunan. Sabuk biasa terdapat pada badan candi, memanjang secara horizontal, dihiasi dengan motif ornamen lain seperti sulursuluran, geometris, bunga, dan lain-lain.

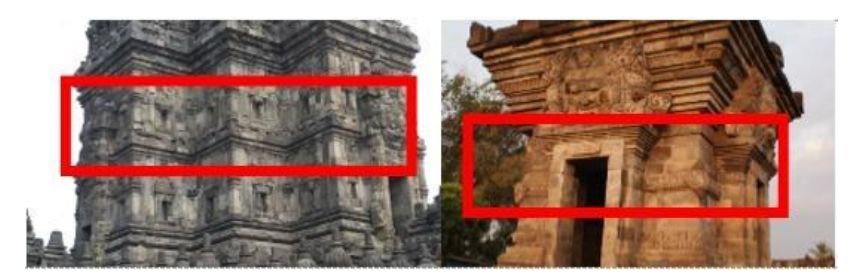

Figur 30. Ornamen Sabuk pada badan Candi Siwa Prambanan dan Candi Angka Tahun Penataran 


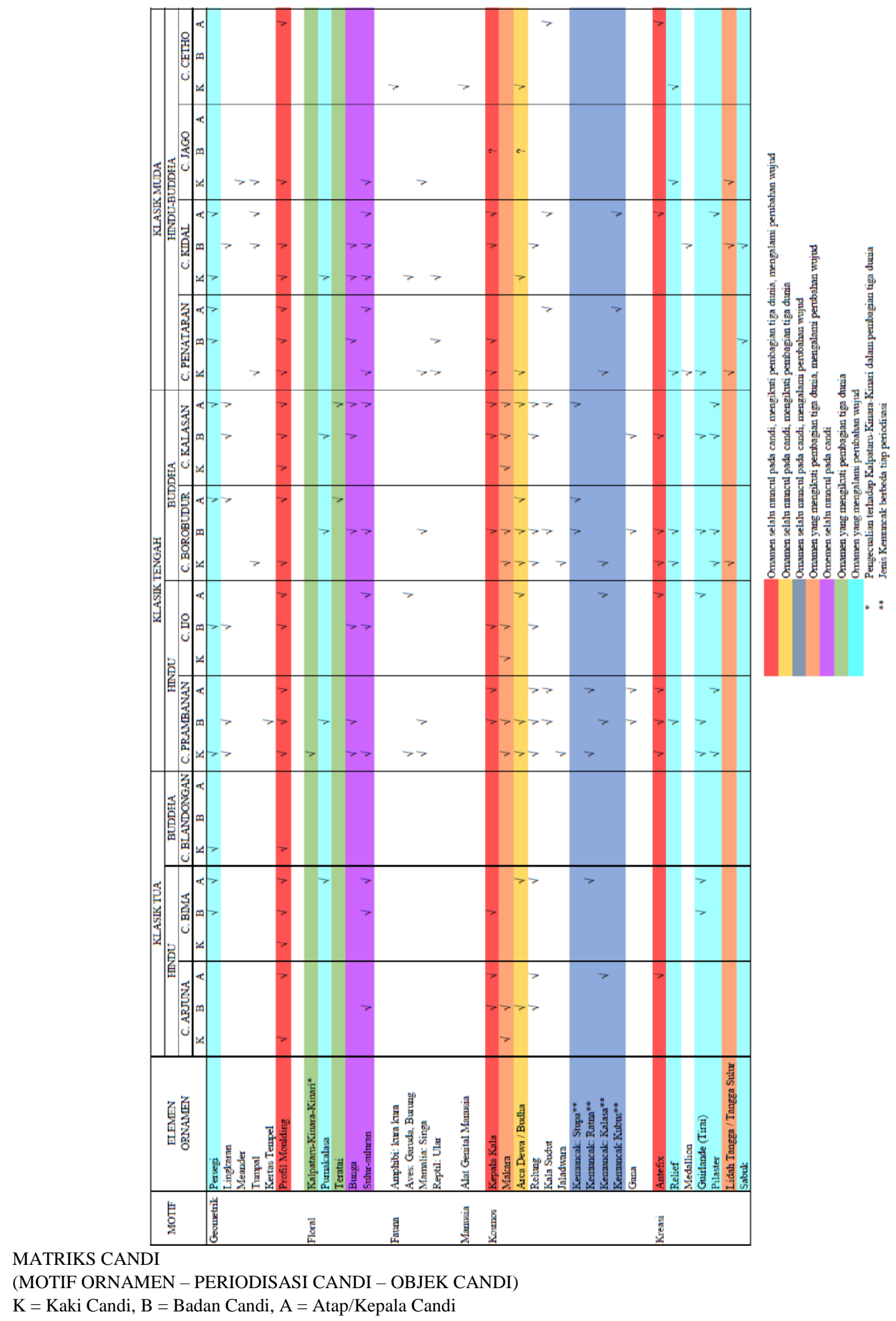




\section{KESIMPULAN}

Akhir dari penelitian ini menjawab pertanyaan penelitian: bagaimana makna ornamen pada elemen bangunancandi Hindu dan Buddha di pulau jawa, ditinjau dari era Klasik Tua, Klasik Tengah, dan Klasik Muda. Dapat disimpulkan bahwa masingmasing bentuk ornamen memiliki makna, dimana perletakan masing-masing ornamen tersebut tidak dapat ditempatkan sembarang. Pemaknaan dalam perletakan ornamen pada ajaran Hindu dan Buddha dapat dikaitkan kedalam tiga elemen candi, yakni kaki candi melambangkan dunia bawah, badan candi melambangkan dunia tengah, dan kepala candi melambangkan dunia atas.

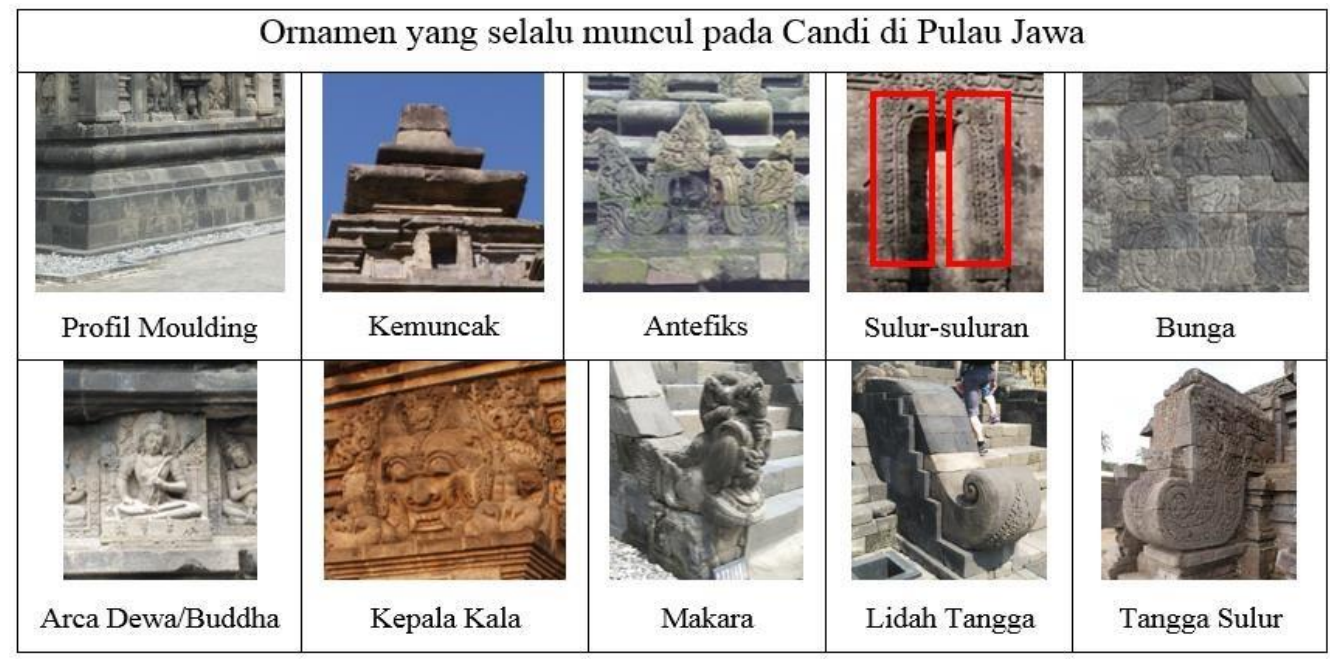

Figur 31. Daftar ornamen yang selalu muncul pada Candi di Pulau Jawa

Ornamen yang menjadi ciri khas dan yang selalu muncul pada candi yakni Profil Moulding, Kemuncak, Antefix, Motif Sulur-suluran, Motif Bunga, Arca Dewa atau Buddha, Kepala Kala, pinggir anak tangga berupa Makara, 'Lidah Tangga', maupun 'Tangga Sulur'. Ornamen yang menjadi ciri khas candi Hindu yakni Arca Dewa dan Relung, dengan kemuncak berupa Kalasa dan Ratna. Sedangkan ornamen khas candi Buddha yakni Arca Buddha dan Relung, Kemuncak Stupa dan bunga Teratai. Ornamen yang tidak dipengaruhi religi baik Hindu maupun Buddha namun selalu muncul antara lain Profil Moulding, Antefix, Bunga, Sulur-suluran, Kepala Kala, Makara, dan lain-lain.

Ornamen yang selalu muncul pada candi era Klasik Tua antara lain: Profil Moulding. Sedangkan ornamen Sulur-suluran, Kepala Kala, Arca Dewa, Relung, dan Kemuncak terdapat pada Candi Arjuna dan Candi Bima. Penggunaan motif ornamen terbilang sedikit dan lebih polos, dimungkinkan karena pengaruh seni, pengetahuan, dan teknologi pemahatan ornamen yang belum berkembang pesat seperti pada candi era Klasik Tengah dan Klasik Muda.

Ornamen yang selalu muncul pada candi era Klasik Tengah antara lain: Profil Moulding, Motif Persegi, Motif Lingkaran, Motif Bunga, Motif Sulur-suluran, Kepala Kala, Makara, Arca Dewa atau Buddha, Relung, Kemuncak, Antefix, dan Guirlande. Sedangkan ornamen Purnakalasa, Kala Sudut, Gana, dan Pilaster hampir ditemukan pada candi era Klasik Tengah. Jumlah motif ornamen yang digunakan sangat bervariasi dan banyak, memberikan kesan bahwa ornamen pada candi Klasik Tengah lebih 'keriting' namun tetap berpola dan rapih.

Ornamen yang selalu muncul pada candi era Klasik Muda antara lain: Profil Moulding, Motif Fauna (masing-masing candi memiliki jenis fauna yang berbeda), dan Arca 
Dewa atau Buddha. Sedangkan ornamen Motif Tumpal, Sulur-suluran, Kepala Kala, Kala Sudut, Relief, dan 'Lidah Tangga' ('Tangga Sulur') hampir dijumpai pada seluruh candi era Klasik Muda. Ornamen pada candi era Klasik Muda tidak sevariatif pada candi era Klasik Tengah, tetapi jenis elemen ornamen yang ditampilkan lebih beragam, individualis dan acak, tidak serapih candi di era Klasik Tengah meskipun perletakan ornamen sangat kompleks dan rumit.

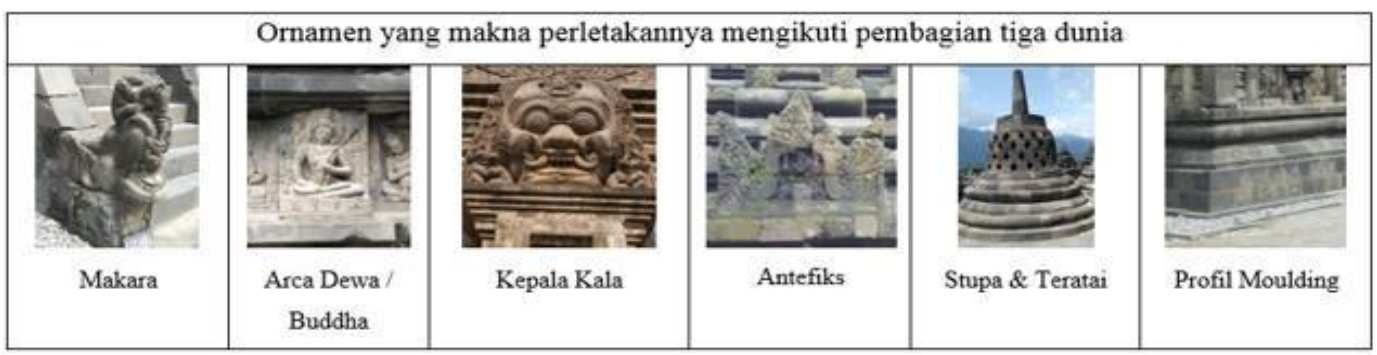

Figur 32. Daftar ornamen yang makna perletakannya mengikuti pembagian tiga dunia

Ornamen yang makna perletakannya mengikuti pembagian tiga dunia (dunia bawah, dunia tengah, dan dunia atas) sesuai ajaran Hindu dan Buddha antara lain: Makara, 'Lidah Tangga', dan 'Tangga Sulur' selalu menempati dunia bawah (kaki candi), Arca Dewa (satu kesatuan dengan relung) berdasarkan hierarki atau tingkatan dewa dan arah hadapnya. Kepala Kala selalu menempati dunia tengah (penjaga pintu masuk, badan candi), Antefix sebagai mahkota selalu menempati dunia atas (kepala candi), Stupa dan Motif Teratai selalu menempati dunia atas. Terdapat ornamen yang perletakannya anomali, yakni KalpataruKinara-Kinari. Kalpataru yang digambarkan sebagai pohon kehidupan (pohon kahyangan) dijaga oleh Kinara - Kinari (sepasang makhluk kahyangan), seharusnya diletakkan di dunia atas yang menggambarkan dunia kahyangan, namun perletakannya ditemukan berada pada kaki candi. 


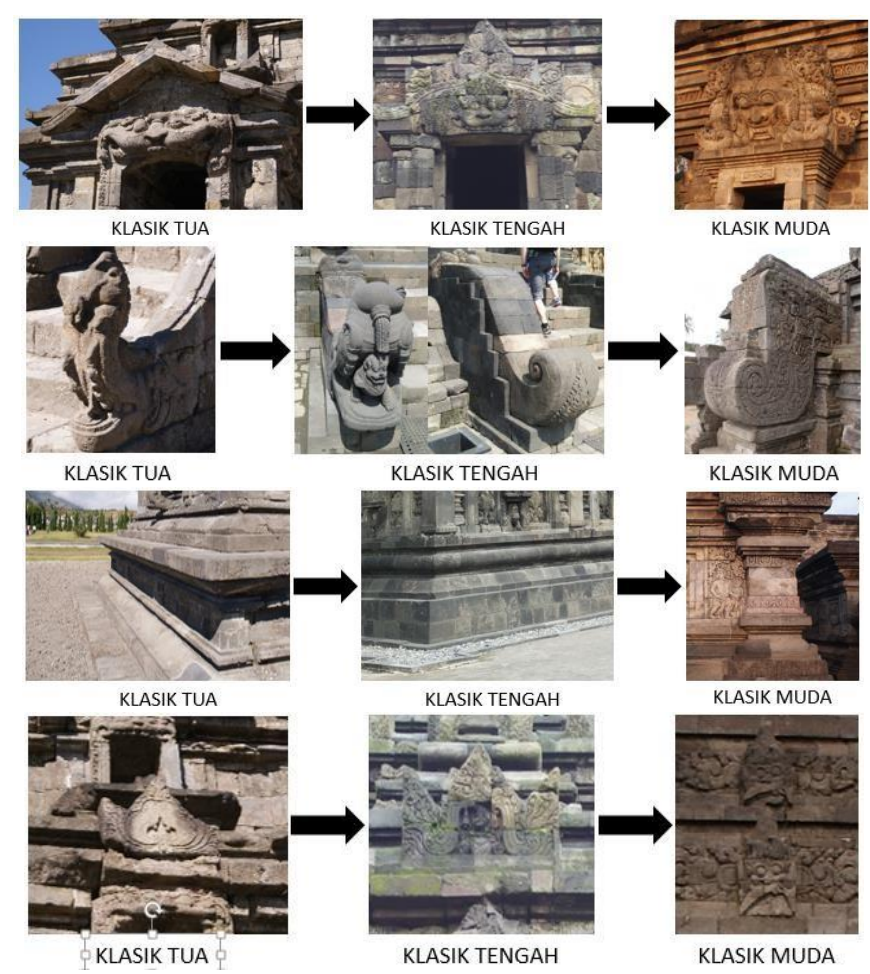

Figur 33. Kepala Kala - Makara - Antefiks - Profil Moulding mengalami perubahan wujud fisik

Ornamen yang mengalami perubahan wujud dari era Klasik Tua - Klasik Tengah Klasik Muda antara lain: Profil Moulding, Motif Persegi, Purnakalasa, Kepala Kala, pengapit tangga candi yakni Makara - 'Lidah Tangga' - 'Tangga Sulur', Relief Naratif, Kemuncak, Antefix, Guirlande, Pilaster dan Sabuk. Motif lain seperti Sulur-suluran, Motif Bunga, Arca Dewa atau Buddha digambarkan sesuai dengan kreatifitas dan teknik pahat dari pembuat candi. Bentuk ornamen pada candi Klasik Tua lebih polos dan sederhana, dengan teknik pahatan timbul. Pada candi Klasik Tengah, bentuk ornamen lebih bervariasi dan keriting namun tertata rapi, dengan teknik pahatan timbul Pada candi Klasik Muda, bentuk dan jenis ornamen lebih ekspresif (simbolis, stilirisasi tidak naturalis), tetapi lebih acak karena hasil ornamen tergantung pada kreatifitas pemahat candi yang individualis. Kualitas teknik pahatan pada candi Klasik Muda lebih rendah dan tipis, kecuali pada arca dewa yang hierarki nya lebih tinggi dari ornamen yang masih terukir timbul dan bagus. Perubahan wujud fisik ornamen berdasarkan waktu tersebut diketahui tidak mengubah makna pada masingmasing ornamen.

Ornamen yang bersifat struktural antara lain Persegi dan Lingkaran (sebagian), Profil Moulding, Kepala Kala, Makara, Relung, Jaladwara, Kemuncak, 'Lidah Tangga' dan 'Tangga Sulur'. Sedangkan ornamen yang bersifat estetis antara lain: Persegi dan Lingkaran (sebagian), Motif Meander, Motif Tumpal, 'Kertas Tempel', Kalpataru-Kinara-Kinari, Purnakalasa, Teratai, Motif Bunga, Sulur-suluran, seluruh Motif Hewan (kecuali singa pada kaki Candi Kidal), Alat Genital Manusia, Arca Dewa atau Buddha, Kala Sudut, Gana, Antefix, Relief Naratif, Medallion, Guirlande, Pilaster, dan Sabuk.

Melihat dari segi kuantitas ornamen yang dihadirkan, maka semakin ke atas semakin sedikit, dimana mengikuti prinsip pembagian tiga dunia, dimana dunia atas merupakan dunia yang suci dan tenang, ketiadaan wujud yang sempurna. Secara kuantitas, perletakan ornamen candi secara keseluruhan mengikuti pembagian tiga dunia, namun masing-masing maknanya tidak selalu 
mengikuti perletakan tersebut. Perkembangan era klasik yang terlihat pada wujud fisik ornamen (bentuk, kualitas dan teknik pahatan) diketahui tidak mengubah makna dari ornamen itu sendiri.

Dari hasil analisis dan kesimpulan ini, terlihat bahwa bagaimana sebuah ornamen sangat bermakna dan diterapkan pada elemen bangunan candi, tidak hanya sebagai hiasan yang mempercantik penampilan candi namun mewakilkan makna simbolis. Sehingga penelitian ini dapat dikembangkan lebih jauh (afterthought) mengenai peran ornamen dalam ranah arsitektur.

Ornamen dalam arsitektur berperan sebagai simbol. Apabila melihat dari era Klasik, ornamen sangat penting mengingat penggunaannya yang sering dan bermakna simbolis tertentu, menunjukan ekspresif yang tinggi. Namun dalam era modern, simbol menjadi hal yang haram dan ditolak, segala sesuatu diekspresikan dengan bentuk dan fungsi tidak lagi disimbolkan menjadi suatu bentuk (ornamen). Namun dalam era post-modern, penggunaan ornamen kembali diminati, semakin berkembang dan semakin bervariasi, dimana ornamen selain sebagai makna simbol, juga digunakan untuk elemen estetis dan dekoratif. Melalui perkembangan ini, dapat disimpulkan bahwa ornamen memegang peranan penting dalam arsitektur, selain sebagai makna simbolis juga merepresentasikan kepribadian dari arsitektur itu sendiri.

Ornamen dalam arsitektur candi sudah sangat jelas memiliki kedudukan yang penting. Melalui ornamen yang memiliki makna simbolis, dapat diketahui bagaimana sejarah candi, fungsi candi, ritual masyarakat, orientasi, posisi, hierarki, bahkan hingga aspek privat - publik. Sejarah diketahui dari wujud fisik bentuk ornamen dapat merepresentasikan pada era Klasik apa candi tersebut dibangun. Fungsi candi diketahui dari ornamen arca apakah dewa atau Buddha atau tidak ada arca, dapat merepresentasikan fungsi candi apakah sebagai tempat pemujaan dewa atau nenek moyang. Ritual masyarakat diketahui dari relief naratif dan ornamen lain, apabila relief naratif dibaca mengelilingi candi searah jarum jam (Pradaksina) maka candi ditujukan untuk penghormatan kepada dewa, sedangkan apabila dibaca berlawanan arah jarum jam (Prasawiya) maka candi ditujukan untuk penghormatan kepada nenek moyang. Orientasi dapat dilihat dari letak arca dewa tertentu, misalkan menghadap gunung atau timur. Posisi dilihat melalui penempatan ornamen kedalam tiga dunia, yakni dunia bawah - dunia tengah - dunia atas. Hierarki dilihat dari jumlah ornamen dimana semakin tingkatan ke atas maka semakin sedikit pula ornamen yang dijumpai, menunjukan area yang paling suci, ketiadaan wujud yang sempurna. Privat-publik dilihat dari adanya area halaman sebagai area publik, selasar dalam candi sebagai area semi-publik, tangga sebagai area semi-privat, dan ruang dalam sebagai area privat, area yang disakralkan. Ornamen dalam arsitektur candi, terutama pada era Klasik Muda, terwujud lebih ekspresif dan puitik, menggambarkan semangat / spirit era klasik dimana akhirnya menjadi ciri khas dari candi era klasik

Ornamen berperan penting untuk arsitektur Indonesia, karena melalui ornamen yang tercermin dalam candi menjadikannya sebagai ciri ragam hias arsitektur khas Indonesia, menjadi sebuah karakter dan identitas bahwa ragam hias berupa ornamen adalah ragam hias lokal milik bangsa Indonesia. Penggunaan ornamen tidak hanya berdampak bagi arsitektur, tetapi pada aspek lain seperti batik pada kain. Motif yang digunakan dalam membatik merupakan ragam hias yang sama dengan ornamen pada candi, dimana saat ini batik telah diakui dunia menjadi identitas nasional bangsa Indonesia. Tentunya berbicara soal identitas bangsa Indonesia, baik dari segi arsitektur, budaya, pakaian, dan sebagainya tidak terlepas dari ragam hias ornamen. 


\section{DAFTAR PUSTAKA}

Dokumentasi HIBAH Dikti, 2009-2016

Herwindo, Rahadhian Prajudi. (2003). Kajian Estetika Desain Arsitektur Majapahit. Bandung: Lembaga Penelitian Universitas Katolik Parahyangan.

Herwindo, Rahadhian Prajudi. (1999). Kajian Tipo-Morfologi Arsitektur Candi di Jawa, Buku 1. Bandung: Tesis Magister ITB.

Herwindo, Rahadhian Prajudi. (1999). Kajian Tipo-Morfologi Arsitektur Candi di Jawa, Buku 2. Bandung: Tesis Magister ITB.

Hoop, A.N.J. Th. A Th. Van Der (1949). Indonesische Siermotieven Ragam-ragam Perhiasan Indonesia Indonesian Ornamental Design. Neatherland: Koninklijk Bataviaasch Genootschap van Kunsten en Wetenschappen

Kempers, A.J. Bernet (1959). Ancient Indonesian Art. C.P.J. van der Peet, Amsterdam: N.V. Boekhandel Antiquariaat en Uitgeverij.

Kinney, Ann R., Marijke J. Klokke \& Lydia Kieven (2003). Worshipping Siva and Buddha: The Temple Art of East Java. Honolulu: University of Hawai'I Press.

Kaulacara, Ramacandra (1966). Silpa Prakasa: Medieval Orissan Sanskrit Text on Temple Architecture. Leiden: E.J. Brill

Press, Pepin Design Book. (1988). Indonesian Ornamental Design. Amsterdam and Singapore: The Peppin Press.

SenSharma, Deba Brata (1990). The Philosophy of Sadhana: With Special Reference to the Trika Philosophy of Kashmir. Albany, N.Y.: State University of New York Press. 